\title{
PENGARUH PERSEPSI GURU SMP TERHADAP MINAT MEMANFAATKAN INTERNET SEBAGAI SUMBER BELAJAR
}

\author{
Elistya Rimawati ${ }^{1)}$ Sri Harjanto ${ }^{2)}$ \\ ${ }^{1)}$ Program Studi Sistem Informasi ,STMIK Sinar Nusantara Surakarta \\ ${ }^{2)}$ Program Studi Manajemen Informatika, STMIK Sinar Nusantara Surakarta, \\ ${ }^{1)}$ elistyarimawati@gmail.com, ${ }^{2}$ hrjanto@gmail.com
}

\begin{abstract}
This study is aimed at measuring the teachers' interest in using internet as the source of study related with the variables perception of information technology, easiness, and risk. The measurement of the variables' influence is conducted to find out the teachers' readiness in using internet in their teaching. The samples of the study are the teachers of either public or private junior high schools in Surakarta residence. The data used in this study is the primary data gained by distributing questionaires randomly. The result of the analysis is that the technology perception positively influences the teachers' interest in using internet as the source of study as much as 0.441 while the easiness perception does the same thing as much as 0.465 . On the other hand, the risk perception contributes negative influence of 0.117. The junior high school teachers' decision to use internet as the source of study is 51.3\% influenced by the preception of information technology, the easiness perception, and the risk perception while $48.7 \%$ is influenced by other factors excluded in this study. The results of this study can be used as a basis for policy making resource development of teachers.
\end{abstract}

Keywords: information technology, easiness, rick, interest

\section{PENDAHULUAN}

Perkembangan teknologi informasi menjadi sarana penunjang yang sangat berguna era globalisasi saat ini. Teknologi informasi digunakan disegala bidang bisnis maupun keilmuan. Perkembangan teknologi informasi juga mempercepat perkembangan ilmu pengetahuan, sehingga semua tingkat pendidikan dapat mempergunakan teknologi informasi.

Komputer merupakan salah satu teknologi informasi yang sudah digunakan dalam dunia pendidikan, dari mulai playgroup hingga perguruan tinggi. Komputer dapat digunakan sebagai media pembelajaran yang interaktif. Adanya komputer yang didukung dengan akses internet memudahkan pencarian dan penyediaan bahan ajar. Internet juga mendukung pembelajaran berbasis online(eLearning) yang memungkinkan terjadi perubahan pada minat dan gaya belajar siswa.

Pemanfaatan internet dan motivasi belajar berpengaruh positif terhadap kegiatan belajar siswa. Pemanfaatan internet dan motivasi belajar berpengaruh 0.301 terhadap kegiatan belajar, jadi ada faktor-faktor lain diluar ini yang mempengaruhi kegiatan belajar siswa.(Tomo \& Utami, 2016)

Internet mempengaruhi hasil belajar siswa Ramansah (2015) dalam penelitiannya yang berjudul "Pemanfaatan Internet sebagai sumber belajar Pendidikan Agama Islam di Sekolah Menegah Pertama Al-Islah Pekanbaru” menyimpulkan bahwa, pemanfaatan internet sebagai sumber belajar pendidikan 
agama Islam di Sekolah Menengah Pertama Al-Ishlah Kecamatan Lima Puluh Pekanbaru "baik"., karena prosentase nilai terakhir 92,98\% berada pada angka 75 - $100 \%$. Adapun faktor yang mempengaruhi pemanfaatan internet sebagai sumber belajar adalah pengawasan yang kontinu dari orang tuadan status sosial ekonomi.

Penelitian tersebut diatas tidak membahas faktor persepsi kemudahan dan resiko yang muncul dalam pengambilan keputusan pemanfaatan internet sebagai sumber belajar Banyak informasi yang bisa kita peroleh dari internet namun semua itu ada lebih ada kurangnya. Keterbukaan informasi bisa memudahkan kita tapi disisi lain bisa berisiko karena ada informasi-informasi tertentu yang seharusnya belum waktunya diketahui untuk usia-usia tertentu. Guru yang mempunyai fungsi sebagai fasilitator dan mediator tentunya mempunyai peran yang sangat penting dalam merekomendasikan sumber belajar kepada siswasiswinya. Dalam merekomendasikan internet sebagai sumber belajar perlu dipertimbangkan beberapa aspek, diantaranya adalah persepsi mengenai teknologi tersebut, kemudahan pengaksesan, dan resiko yang timbul dari akses internet tersebut.

Penelitian ini menfokuskan pada permasalahan : (1) Pengaruh persepsi teknologi informasi terhadap minat guru SMP dalam pemanfaatan internet sebagai sumber belajar siswa. (2) Pengaruh persepsi kemudahan terhadap minat guru SMP dalam pemanfaatan internet sebagai sumber belajar siswa. (3) Pengaruh persepsi resiko terhadap minat guru SMP dalam pemanfaatan internet sebagai sumber belajar siswa.

Batasan masalah : (1) Pada penelitian ini yang dimaksud dengan "Persepsi atas Teknologi Informasi" yaitu persepsi guru terhadap teknologi internet yang digunakan atau direkomendasikan kepada siswa, "Persepsi Kemudahan" adalah persepsi guru terhadap kemampuan siswa dalam menggunakan internet, "Persepsi Resiko" adalah persepsi guru atas resiko terhadap siswa yang timbul jika para siswa mengakses internet. (2) Guru Sekolah yang menjadi obyek penelitian adalah Guru SMP Negeri dan Swasta di Surakarta dan sekitarnya.

Tujuan penelitian adalah untuk dapat mengetahui pengaruh persepsi teknologi informasi, persepsi kemudahan dan persepsi resiko terhadap minat guru SMP dalam pemanfaatan internet sebagai sumber belajar siswa di Surakarta.Untuk mengetahui proses pembelajaran mandiri yang tepat untuk siswa SMP

Hipotesis yang akan dibuktikan adalah

a. $\mathrm{H}_{0}$ : Tidak ada pengaruh positif persepsi teknologi informasi terhadap minat guru SMP memanfaatkan internet sebagai sumber belajar.

$\mathrm{H}_{1}$ : Ada pengaruh positif variabel teknologi informasi terhadap minat guru SMP memanfaatkan internet sebagai sumber belajar.

b. $\mathrm{H}_{0}$ : Tidak ada pengaruh positif persepsi kemudahan terhadap minat guru SMP memanfaatkan internet sebagai sumber belajar.

$\mathrm{H}_{1}$ : Ada pengaruh positif variabel kemudahan terhadap minat guru SMP memanfaatkan internet sebagai sumber belajar

c. $\mathrm{H}_{0}$ : Tidak ada pengaruh positif persepsi resiko terhadap minat guru SMP memanfaatkan internet sebagai sumber belajar.

$\mathrm{H}_{1}$ : Ada pengaruh positif variabel resiko terhadap minat guru SMP memanfaatkan internet sebagai sumber belajar. 
d. $\mathrm{H}_{0}$ : Tidak ada pengaruh positif persepsi teknologi informasi, persepsi kemudahan dan persepsi resiko terhadap minat guru SMP memanfaatkan internet sebagai sumber belajar.

$\mathrm{H}_{1}$ : Ada pengaruh positif antara teknologi informasi, persepsi kemudahan dan resiko terhadap minat guru SMP memanfaatkan internet sebagai sumber belajar.

\section{TINJAUAN PUSTAKA}

Teknologi dapat meningkatkan kinerja pembelajaran lebih berkualitas. Agar mendapat proses dan hasil belajar siswa yang berkualitas, guru harus memiliki penguasaan terhadap materi, strategi dan metode pembelajaran serta penguasaan teknologi sebagai media dan pengorganisasi pembelajaran. Teknologi informasi membantu memecahkan masalah yang lebih efektif dan efisien, sehingga kinerja dapat lebih ditingkatkan. Davis et al. (1989) mendefinisikan Perceived usefulness adalah tingkat kepercayaan seseorang menggunakan sistem tertentu dapat meningkatkan kinerja. Sesuai dengan technology acceptance model (TAM), penggunaan sistem (actual system usage) dipengaruhi oleh minat untuk menggunakan (behavioral intentions toward usage). Kepercayaan seseorang terhadap persepsi pengguna terhadap manfaat (perceived usefulness) dan persepsipengguna terhadap kemudahan (perceived ease of use).

Internet dapat digunakan semua lapisan stata pendidikan. Penggunaan internet tidak berakibat kesalahan yang fatal. Perceived ease of use didefinisikan Davis et al., (1989), merupakan seberapa besar teknologi komputer dirasakan relatif mudah untuk dipahami dan digunakan. Persepsi seseorang berkaitan dengan kemudahan dalam menggunakankomputer (perceived ease of use) merupakan tingkat kepercaya seseorang bahwa menggunakan sistem tertentu akan bebas dari kesalahan. Persepsi akan berdampak pada perilaku, yaitu semakin tinggi persepsi seseorangtentang kemudahan menggunakan sistem, semakin tinggi pula tingkat pemanfaatan teknologi informasi. Kemudahan teknologi informasi mendorong seseorang untuk memanfatkan teknologi yang berdaya guna dan mengembangkan fungsi dan manfaatnya.

Resiko adalah suatu keadaan uncertainty yang dipertimbangkan orang untukmemutuskan atau tidak menggunakan internet sebagai sumber belajar. Resiko didefinisikan sebagai peluang terjadinya hasil yang tidak diinginkan, sehingga resiko terkait dengan situasi yang memungkinkan munculnya hasil negatif serta berkaitan dengan kemampuan memperkirakan terjadinya hasil negatif tadi (Basyaib, 2007). Resiko didefinisikan sebagai perkiraan subyektif konsumen untuk menderita kerugiandalam menerima hasil diinginkan.Resiko itu meningkat dari sekedar informasi sampai pada keputusan penggunaan produk, resiko diasosiasikan dengan kepercayaan. Dalam penelitian ini indikator resiko dilihatdari faktor-faktor yang muncul dan merugikan dalam penggunakan internet sebagai sumber belajar.

Pemanfaatan teknologi menunjukkan keputusan individu untuk memilih menggunakan atau tidak menggunakan teknologi dalam menyelesaikan berbagai pekerjaan. Pemanfaatan teknologi diukur dengan seberapa besar proporsi pemakai memilih untuk memanfaatkan sistem. TAM (technology acceptance model) adalah salah satu model perilakupemanfaatan teknologi informasi dalam literatur sistem informasi manajemen. Model ini menyediakan dasar teori untuk 
menelusurifaktor yang menjelaskan pemakaian software dan menghubungkannya dengankinerja pemakai. TAM berfokus pada sikap terhadap pemakaian teknologiinformasi oleh pemakai, dengan mengembangkannya berdasarkan persepsimanfaat dan kemudahan dalam pemakaian teknologi informasi. TAM merupakan satu di antara banyak model penelitian yang berpengaruh dalam studi determinanakseptasi teknologi informasi. TAM banyak digunakan untuk memprediksitingkat akseptasi pemakai (user acceptance) dan pemakaian yang berdasarkanpersepsi terhadap kemudahan penggunaan dan manfaat teknologi informasi. Implikasi akseptasi dapat dipelajari dengan menguji hubungan antara akseptasi teknologi informasi dan dampaknya kepada pemakai individual. Internet merupakan kependekan dari interconnected networking atau international networking, yaitu kumpulan yang sangat luas dari jaringan komputer besar dan kecil yang saling berhubungan dengan menggunakan jaringan komunikasi yang ada di seluruh dunia. Pembelajaran berbasis web merupakan suatu kegiatan pembelajaran yang memanfaatkan media situs (website) yang bias diakses melalui jaringan internet. Materi-materi dalam kegiatan tersebut kebanyakan dihantarkan melalui media internet (Lantip \& Riyanto, 2011). Internet memberikan kemudahan dalam mengembangkan pendidikan dan pengajaran. Namun mempunyai kelemahan yaitu ketersediaan sarana dan prasarana dan perlu didukung dengan tingkat akses yang memadai, (Kristiyanti, 2010).

Sumber belajar adalah segala sesuatu yang tersedia di sekitar lingkungan belajar yang berfungsi untuk membantu optimalisasi hasil belajar. Optimalisasi hasil belajar ini dapat dilihat tidak hanya dari hasil belajar saja, namun juga dilihat dari proses pembelajaran yang berupa interaksi siswa dengan berbagai sumber belajar. Interaksi ini dapat memberikan rangsangan untuk belajar dan mempercepat pemahaman dan penguasaan bidang ilmu yang dipelajari.

AECT (Association for Education and Communication Technology) menyatakan bahwa sumber belajar (learning resources) adalah semua sumber baik berupa data, orang dan wujud tertentu yang dapat digunakan oleh siswa dalam belajar, baik secara terpisah maupun secara terkombinasi sehingga mempermudah siswa dalam mencapai tujuan belajar atau mencapai kompetensi tertentu. Sumber belajar adalah bahan-bahan yang dimanfaatkan dan diperlukan dalam proses pembelajaran, yang dapat berupa buku teks, media cetak, media elektronik, narasumber, lingkungan sekitar, dan sebagainya yang dapat meningkatkan kadar keaktifan dalam proses pembelajaran, (Kristiyanti, 2010).

Ramansah (2015) dalam penelitiannya yang berjudul "Pemanfaatan Internet sebagai sumber belajar Pendidikan Agama Islam di Sekolah Menegah Pertama Al-Islah Pekanbaru" menyimpulkan bahwa, pemanfaatan internet sebagai sumber belajar adalah "baik"., karena prosentase nilai terakhir 92,98\% berada pada angka $75-100 \%$. Adapun faktor yang mempengaruhi pemanfaatan internet sebagai sumber belajar adalah pengawasan yang kontinu dari orang tua terhadap kegiatan belajar siswa di rumah, status sosial ekonomi orang tua siswa yang masih terbilang menengah ke atas sehingga menyebabkan sedikitnya peluang mencari informasi melalui internet, dan banyaknya warnet-warnet yang beredar disekitar SMP Al-Islah sehingga memudahkan siswa mencari informasi pendidikan Agama Islam. Pada penelitian tersebut disampaikan hasil pemanfaatan internet dari sisi peningkatan hasil belajar tetapi tidak di uraikan 
faktor-faktor yang menjadi pertimbangan guru dalam menggunakan internet. Dalam penelitian tersebut juga tidak diuraikan resiko-resiko pemanfaatan internet sebagai sumber belajar

\section{METODOLOGI PENELITIAN}

Populasi yaitu sekelompok orang, kejadian atau segala sesuatu yang mempunyai karakteristik tertentu. Populasi didefinisikan sebagai suatu keseluruhan pengamatan atau obyek yang menjadi perhatian kita (Sunyoto, 2012). Populasi yang akan diteliti disini adalah guru SMPNegeri dan swasta di wilayah Surakarta dan sekitarnya yang pernah dan ingin memanfaatkan Internet sebagai sumber belajar siswa

Sampel adalah bagian dari populasi yang menjadi perhatian dari kita. Teknik yang digunakan pengambilan sampel adalah simple random sampling.Kriteria sampel yaitu guru SMP yang memanfaatkan internet sebagai sumber belajarsiswa di wilayah Surakarta dan sekitrnya. Perkiraan jumlah populasi sebanyak 1.968(data peserta UKK-SMP 2015) diambil sampel sebanyak $10 \%$ yaitu 197 orang.

Variabel dalam penelitian ini adalah :

a. Variabel bebas, terdiri dari :

1. Persepsi atas Teknologi Informasi yaitu persepsi guru terhadap teknologi internet yang digunakan atau direkomendasikan kepada siswa.

2. Persepsi terhadap kemudahan menggunakan internet adalah persepsi guru terhadap kemampuan siswa dalam menggunakan internet.

3. Persepsi atas resiko adalah persepsi guru atas resiko terhadap siswa yang timbul jika para siswa mengakses internet.

b. Variabel terikat,

Variabel terikat dalam penelitian ini adalah minat guru SMP dalam pemanfaatan internet sebagai sumber belajar siswa.

Pada penelitian ini akan digunakan teknik kuesioner ( angket ) yaitu cara mengumpulkan data dengan mengirim kuesioner yang berisi sejumlah pernyataan yang ditujukan kepada orang yang menjadi obyek penelitian. Skala pengukuran yang digunakan adalah skala Likert dengan skala seperti pada Tabel 1

Tabel 1. Skala Likert

\begin{tabular}{cccc}
\hline NO & Jawaban & Kode & Nilai \\
\hline 1 & Sangat Tidak Setuju & STS & 1 \\
2 & Tidak Setuju & TS & 2 \\
3 & Cukup Setuju & CS & 3 \\
4 & Setuju & S & 4 \\
5 & Sangat Setuju & SS & 5 \\
\hline
\end{tabular}

Metoda analisis data yang digunakan dalam penelitian ini adalah analisi regresi linier ganda, uji t, uji F, koefisien determinasi dan asumsi klasik yaitu ujinormalitas,multikolonieritas, heteroskedastisitas dan Autokorelasi. Adapun tahapan-tahapanya adalah sebagai berikut : 


\section{Analisis Regresi Linier Berganda}

Metoda analisis dalam penelitian ini menggunakan perhitungan regresi linier berganda dengan model persamaan sebagai berikut :

$$
y=\beta_{0}+\beta_{1} x_{1}+\beta_{2} x_{2}+\beta_{3} x_{3}+e
$$

Keterangan :

$\beta_{0} \quad=$ koefisien kontanta

$\beta_{1}, \beta_{2}, \beta_{3}=$ koefisien regresi

$x_{1}=$ persepsi teknologi informasi

$x_{2} \quad=$ persepsi kemudahan

$x_{3} \quad=$ persepsi resiko

$y=$ minat guru SMP memanfaatkan internet

e $\quad=$ error

\section{Pengujian Hipotesis}

Uji hipotesis dalam penelitian ini dilakukan terhadap hipotesis statistik menggunakan uji t dan uji $\mathrm{F}$.

\section{HASIL DAN PEMBAHASAN \\ Data Responden}

Jumlah sampel dalam penelitian ada 200 responden yaitu guru-guru yang pernah menggunakan internet dari 12 SMP ( SMP N 2 Surakarta, SMP N 9 Surakarta, SMP N 23 Surakarta, SMP N 25 Surakarta, SMP N 3 Colomadu, SMP N 1 Delanggu, SMP N 3 Delanggu, SMP Ta'mirul Islam Surakarta, SMP Batik Surakarta, SMP Muhhamadiyah Program Khusus Surakarta , SMP Al Abidin Surakarta, SMP Insan Cendekia Al Mujtaba Surakarta ) yang dipilih secara random.

\section{Stastistik Deskriptif}

Berdasarkan hasil perhitungan kuesioner diperoleh data seperti pada Tabel 2

Tabel2. Deskriptif

\begin{tabular}{lrrrr}
\multicolumn{5}{c}{ Statistics } \\
\hline X1 & \multicolumn{1}{c}{ X2 } & X3 & \multicolumn{1}{c}{ Y } \\
\hline N Valid & 200 & 200 & 200 & 200 \\
$\quad$ Missing & 0 & 0 & 0 & 0 \\
Mean & 19.9850 & 18.0300 & 18.2100 & 19.2100 \\
Median & 20.0000 & 18.0000 & 18.0000 & 19.5000 \\
Mode & 20.00 & 18.00 & 20.00 & 20.00 \\
Std. Deviation & 2.30027 & 2.87759 & 2.90657 & 2.76662 \\
Minimum & 12.00 & 12.00 & 9.00 & 12.00 \\
Maximum & 25.00 & 25.00 & 25.00 & 25.00 \\
\hline
\end{tabular}

Rerata persepsi teknologi mempunyai nilai yang paling tingggi yaitu 19.9850 dan yang paling kecil adalah persepsi kemudaah yaitu 18.0300. Nilai median pada nilai 18 sampai 20. Dapat disimpulkan sebagian besar responden 
setuju atau mempunyai persepsi yang sama penggunaan internet sebagai sumber belajar siswa dipengaruhi dari pengaruh persepsi teknologi, persepsi kemudahan dan resiko.

Nilai rerata persepsi teknologi merupakan nilai rerata paling tinggi dibanding nilai rerata persepsi kemudahan dan persepsi resiko. Hal ini dikarenakan dengan teknologi dapat membantu suatu pekerjaan dalam hal ini proses transfer ilmu pengetahuan dalam proses pembelajaran. Dengan berkembangnya teknologi informasi pada saat ini maka informasi dapat dengan cepat disebar luaskan.

Komunikasi antara guru, antara guru dan murid dapat lebih mudah dan cepat. Sehingga proses pembelajaran bisa lebih efektif dan efisien, Hasil penelitian Sidiq (2015) menunjukan bahwa jika pembelajaran menggunakan media pembelajaran berbasis teknologi informasi maka aspek fleksibilitas dan efektivitas pembelajaran dilingkungan SDLB dapat terwujud dengan baik.

Rerata resiko nilainya lebih tinggi dibading dengan persepsi kemudahan, hal ini karena guru mempertimbangkan akibat yang akan ditimbulkan dengan menggunakan internet sebagai sumber belajar. Murid SMP merupakan anak remaja yang sedang mengembangkan diri namun dari segi emosionalnya mereka perupakan usia -usia yang ingin menunjukan jatidiri sehingga kontrol emosinya masih kurang. Hal ini yang menjadi salah pertimbangan guru.

Resiko penggunaan internet diharapkan jangan sampai mempengaruhi nilainilai akademik dan juga mempengaruhi perkembangan jiwa anak untuk menuju orang dewasa yang bertanggung jawab dan bermanfaat untuk masyarakat sekitar.

Persepsi kemudahan mengunakan internet ini menjadi pertimbangan guru menggunakan internet menjadi pertimbangan karena guru mempunyai kepercayaan bahwa untuk murid SMP internet bukan hal yang susah dalam pengoperasiannya. Internet pada saat ini bukanlah hal yang mewah karena hampir semua daerah bisa terjangkau jaringan internet. Sehingga setiap siswa bisa mengaksesnya.

\section{Uji Hipotesa}

Uji Regresi

Pengujian menggunakan model regresi linier berganda pada variabel bebas persepsi teknologi informasi $\left(\mathrm{X}_{1}\right)$, persepsi kemudahan $\left(\mathrm{X}_{2}\right)$ dan persepsi resiko $\left(X_{3}\right)$ dan variabel terikat minat guru SMP memanfaatkan internet sebagai sumber belajar (Y) seperti pada Tabel 3.

Tabel 3.. Hasil Analisa Regresi Berganda

\section{Coefficientsa}

\begin{tabular}{|c|c|c|c|c|c|}
\hline \multirow[b]{2}{*}{ Model } & \multicolumn{2}{|c|}{$\begin{array}{c}\text { Unstandardized } \\
\text { Coefficients }\end{array}$} & \multirow{2}{*}{$\begin{array}{c}\begin{array}{c}\text { Standardized } \\
\text { Coefficients }\end{array} \\
\text { Beta }\end{array}$} & \multirow[b]{2}{*}{$\mathrm{t}$} & \multirow[b]{2}{*}{ Sig. } \\
\hline & B & Std. Error & & & \\
\hline 1 (Constant) & 4.133 & 1.458 & & 2.835 & .005 \\
\hline $\mathrm{X} 1$ & .441 & .067 & .367 & 6.621 & .000 \\
\hline $\mathrm{X} 2$ & .465 & .054 & .484 & 8.665 & .000 \\
\hline X3 & -.117 & .048 & -.122 & -2.429 & .016 \\
\hline
\end{tabular}


adalah :

Berdasarkan Tabel3, maka model regresi linier berganda pada penelitian ini

$$
\begin{aligned}
& \mathrm{Y}=4.133+0.441 \mathrm{X}_{1}+0.465 \mathrm{X}_{2}-0.117 \mathrm{X}_{3} \\
& \text { Dimana : } \\
& \mathrm{X}_{1}=\text { persepsi teknologi infomasi } \\
& \mathrm{X}_{2}=\text { persepsi kemudahan } \\
& \mathrm{X}_{3}=\text { persepsi resiko } \\
& \mathrm{Y}=\text { Minat guru SMP memanfaatkan internet }
\end{aligned}
$$

Berdasarkan rumus 2 dapat disimpulkan bahwa variabel bebas yang mempunyai pengaruh paling besar terhadap minat guru SMP memanfaatkan internet sebagai sumber belajar adalah persepsi kemudahan yang ditunjukkan dengan nilai koefisien $b_{2}=0.465$ dan kemudian persepsi teknologi informasi dengan dengan nilai koefisien $b_{1}=0.441$. Variabel bebas yang mempunyai pengaruh paling kecil adalah persepsi resiko dengan nilai koefisien $b=-0.117$, yang artinya semakin tinggi resiko yang mempengaruhi maka semakin berkurang minat guru SMP memanfaatkan internet sebagai sumber belajar. Sedang variabel persepsi teknologi informasi dan kemudahan berpengaruh positif terhadap minat guru menggunakan internet sebagai media belajar.

\section{Uji t ( t test )}

Uji t digunakan untuk mengetahui besarnya pengaruh variabel independen teknologi informasi $\left(\mathrm{X}_{1}\right)$, persepsi kemudahan $\left(\mathrm{X}_{2}\right)$ dan persepsi resiko $\left(\mathrm{X}_{3}\right)$ terhadap variabel dependen minat guru SMP memanfaatkan internet sebagai sumber belajar (Y) secara parsial. Hasil perhitungan menggunakan SPSS dapat kita peroleh pada tabel 3 .

1) Tes hipotesis ada pengaruh positifpersepsi teknologi informasi $\left(X_{1}\right)$ terhadap minat guru memanfaatkan internet sebagai sumbe belajar(Y).

Berdasarkan tabel di atas, nilai thitung untuk persepsi teknologi informasi $\left(\mathrm{X}_{1}\right)$ yaitu : 6.621 dan $\mathrm{t}_{\text {tabel }}$ dengan db 196 dan taraf signifikan 0,05 adalah 1.65 ,sehingga $T_{\text {hitung }}>T_{\text {tabel }}(6.621>1.65)$ maka $H_{o}$ ditolak. Sedang signifikan pada tabel 3. adalah 0.000 yang berarti probabilitas kurang dari $0,05{\text { maka } \mathrm{H}_{\mathrm{o}}}$ ditolak. Hipotesis diterima ini berarti teknologi informasi $\left(\mathrm{X}_{1}\right)$ signifikan dan positif terhadap variabel dependen minat guru memanfaatkan internet sebagai sumber belajar (Y) secara parsial. Positif berarti dengan meningkat persepsi teknologi informasi $\left(\mathrm{X}_{1}\right)$ maka meningkat pula nilai variabel dependen minat guru SMP menggunakan internet sebagai sumber belajar. Teknologi informasi sangat berpengaruh dalam dunia pendidikan hal ini juga sesuai dengan hasil penelitian Qodrin Nurfahmi (2011) bahwa penggunaan teknologi informasi pada pembelajaran berbasis internet mempunyai pengaruh yang signifikan terhadap minat belajar PAI siswa klas VIII SMP N 30 Semarang.

2) Tes hipotesis pengaruh positif persepsi kemudahan $\left(X_{2}\right)$ terhadap minat guru SMP memanfaatkan internet sebagai sumber belajar(Y).

Berdasarkan tabel 3.nilai $t_{\text {hitung }}$ untuk persepsi kemudahan $\left(\mathrm{X}_{2}\right)$ yaitu : 8.665pada $t_{\text {tabel }}$ dengan db 196 dan taraf signifikan 0,05 adalah 1.65 , karena $\mathrm{T}_{\text {hitung }}>\mathrm{T}_{\text {tabel }}(8.665>1.65)$ maka $\mathrm{H}_{\mathrm{o}}$ ditolak. Sedang signifikan pada 
tabel adalah 0.000 yang berarti probabilitas kurang dari 0,05 maka $\mathrm{H}_{\mathrm{o}}$ ditolak. Hipotesis diterima ini berarti kemudahan $\left(\mathrm{X}_{2}\right)$ signifikan dan positif terhadap variabel dependen minat guru SMP memanfaatkan internet sebagai sumber belajar secara parsial. Positif berarti dengan meningkat nilai kemudahan (X2) maka meningkat pula nilai variabel dependen minat guru SMP memfaatkan internet sebagai sumber belajar.Guru menggunakan internet sebagai sumber belajar karena internet mudah penggunaanya apalagi untuk siswa SMP. Davis et al., (1989)menjelaskan bahwa persepsi individu berkaitan dengan kemudahan dalam menggunakan komputer merupakan tingkat dimana individu percayabahwa menggunakan sistem tertentu akan bebas dari kesalahan. Persepsi ini kemudian akan berdampak pada perilaku, yaitu semakin tinggi persepsi seseorang tentang kemudahan menggunakan sistem, semakin tinggi pula tingkat pemanfaatan teknologi informasi.

Salah satu bentuk pemanfaatan internet untuk lembaga pendidikan adalah model blended learning. Model ini memadukan pembelajaran secara tatap muka (tradisional) dengan e-learning. Dengan cara ini, kelebihan masingmasing metode dapat dimanfaatkan secara optimal. Pertemuan tatap muka di kelas dapat dimanfaatkan untuk mendiskusikan bahan-bahan yang tersedia di sistem e-learning. Menurut Mustaqim (2016) hal ini memacu mahasiswa untuk mampu mengatur ritme belajar yang tidak hanya di dalam kelas, tetapi juga di luar kelas. Mahasiswa bisa mengulang pelajaran dengan memutar video pembelajaran kembali dengan waktu tidak terbatas dan tempat yang mudah dijangkau. Berdasarkan hasil penelitian, dapat disimpulkan mahasiswa kelas blended learning lebih baik daripada mahasiswa kelas biasa. Selain itu, mahasiswa kelas blended learning lebih aktif mengerjakan tugas daripada kelas biasa.

3) Tes hipotesis pengaruh positif persepsi resiko $\left(X_{3}\right)$ terhadap minat guru SMP menggunakan internet sebagai sumber belajar.

Berdasarkan tabel 3.nilai $t_{\text {hitung }}$ untuk persepsi resiko $\left(\mathrm{X}_{3}\right)$ yaitu -2.429 pada $t_{\text {tabel }}$ dengan db 196 dan taraf signifikan 0,05 diperoleh 1.65 , karena $\mathrm{T}_{\text {hitung }}<\mathrm{T}_{\text {tabel }}(-2.429>1.65)$ maka $\mathrm{H}_{\mathrm{o}}$ diterima. Sedang signifikan pada tabel adalah 0.016 yang berarti probabilitas kurang dari 0,05 maka $\mathrm{H}_{\mathrm{o}}$ ditolak. Hipotesis ditolak ini berarti resiko $\left(\mathrm{X}_{3}\right)$ signifikan dan tidak berpengaruh positif terhadap variabel dependen minat guru SMP memanfaatkan internet sebagai sumber belajar(Y) secara parsial. Persepsi resiko $\left(\mathrm{X}_{3}\right)$ berpengaruh negatif, semakin sebasar persepsi resiko maka berkurang minat guru SMP memanfaatkan internet sebagai sumber belajar. Guru bertujuan meningkatkan mutu pendidikan sehingga kalau resikonya tinggi jika menggunakan internet maka mereka tidak mau ambil resiko berdampak tidak baik dalam dunia pendidikan.

\section{Uji F}

Pengujian ini digunakan untuk mengetahui apakah semua variabel bebas secara bersama dapat berpengaruh terhadap variabel terikat sehingga model tepat dan baik. Pengujian secara simultan hasilnya seperti pada Tabel 4. 
Tabel 4. Hasil Analisis Uji F

\begin{tabular}{|c|c|c|c|c|c|c|}
\hline \multicolumn{7}{|c|}{ ANOVA $^{\text {b }}$} \\
\hline & Model & $\begin{array}{l}\text { Sum of } \\
\text { Squares }\end{array}$ & $D f$ & $\begin{array}{l}\text { Mean } \\
\text { Square }\end{array}$ & $F$ & Sig. \\
\hline \multirow[t]{3}{*}{1} & Regression & 781.516 & 3 & 260.505 & 68.844 & $.000^{\mathrm{a}}$ \\
\hline & Residual & 741.664 & 196 & 3.784 & & \\
\hline & Total & 1523.18 & 199 & & & \\
\hline
\end{tabular}

a. Predictors: (Constant), X3, X1, X2

b. Dependent Variable: Y

Nilai F $=68.844$ dan tingkat Sgnifikan 0.000 artinya vaiabel variabel bebas teknologi informasi $\left(\mathrm{X}_{1}\right)$, persepsi kemudahan $\left(\mathrm{X}_{2}\right)$ dan persepsi resiko $\left(\mathrm{X}_{3}\right)$ secara bersama-sama mempunyai pengaruh yang berarti terhadap minat guru SMP memanfaatkan internet sebagai sumber belajar. Model regresi linier berganda : $\mathrm{Y}=4.133+0.441 \mathrm{X}_{1}+0.465 \mathrm{X}_{2}+(-0.117) \mathrm{X}_{3}$ sudah tepat. Jadi keputusan guru menggunakan internet sebagai sumber belajar siswa dipengaruhi oleh persepsi teknologi, kemudahan dan mempertibangkan resiko.

\section{Koefisien Derminasi}

Hasil olah data hubungan antar variabel dapat dilihat pada tabel 5.

Tabel.5 Hasil Analisis Koefisien Determinasi

Model Summary

\begin{tabular}{rlrrr}
\hline Model & $R$ & $R$ Square & $\begin{array}{c}\text { Adjusted } R \\
\text { Square }\end{array}$ & $\begin{array}{c}\text { Std. Error of the } \\
\text { Estimate }\end{array}$ \\
\hline 1 & $.716^{\mathrm{a}}$ & 0.513 & 0.506 & 1.94525 \\
\hline
\end{tabular}

a. Predictors: (Constant), X3, X1, X2

Berdasarkan Tabel 5 diperoleh nilai koefisien korelasi berganda $\mathrm{R}=0.716$, hal ini menunjukkan hubungan antara variabel bebas persepsi teknologi informasi $\left(\mathrm{X}_{1}\right)$, persepsi kemudahan $\left(\mathrm{X}_{2}\right)$ dan persepsi resiko $\left(\mathrm{X}_{3}\right)$ dengan variabel terikat minat guru (Y) menggunakan internet sebagai sumber belajar besarnya 71,6\% sudah mendekati nilai 1 . Hal ini dapat disimpulkan hubungannya sangat erat dan positif.

Berdasarkan tabel 5. diperoleh nilai $\mathrm{R}$ Square $=0.513$. Nilai ini menunjukkan sumbangan pengaruh variabel bebas persepsi teknologi informasi $\left(\mathrm{X}_{1}\right)$, persepsi kemudahan $\left(\mathrm{X}_{2}\right)$ dan persepsi resiko $\left(\mathrm{X}_{3}\right)$ terhadap minat guru SMP memanfaatkan internet sebagai sumber belajar(Y) adalah 51,3\% sedang sisanya sebesar $48,7 \%$ dari adalah faktor-faktor lain yang tidak masuk dalam penelitian seperti sarana sekolah, tingkat jangkauan internet disetiap daerah dan juga faktor ekonomi.

Minat guru menggunakan internet sebagai sumber belajar dipengaruhi oleh persepsi teknologi informasi karena teknologi informasi dapat mendukung dalam proses pembelajaran. Internet dapat membantu guru dalam menjelaskan materi yang memerlukan bantuaan multimedia, dengan adanya internet dapat memperoleh informasi yang lebih banyak.Manfaat internet bagi pendidikan 
adalah dapat mengakses sumber informasi, mengakses nara sumber, dan sebagai media kerjasama.Internet mempermudah pembelajaran karena tidak dibatasi ruang dan waktu, sehingga pertukaran informasi dan ilmu pengatahuan di antara murid dan guru, murid dengan murid, guru dengan guru dapat berlangsung di mana saja dan kapan saja. Pembelajaran lebih efektif dan efisien. Teknologi informasi juga mendidik murid belajar mandiri. Menurut Wuryandari (2016) stategi guru mengimplementasikan karakter pendidikan mandiri adalah dengan penugasan yang menuntut siswa memanfaatkan perpustakaan dan internet sebagai sumber belajar, mengkreasikan kelas menurut kreasi masing-masing siswa, membuat kontrak pada masing-masing klas sesuai kesepakantan. Menurut Rochmawati ( 2012) mayoritas responden yang masih anak-anak tertarik menggunakan internetkarena kepentingan informasi, dan mayoritas responden yang tertarik menggunakan internet untuk kepentingan informasi adalah sebanyak 37 orang atau sekitar $46,8 \%$. Berdasarkan hasil temuan data tersebut dapat diketahui bahwa sebagian responden yang masih anak -anak menggunakan internet karena kepentingan informasi. Hal ini dikarenakan bahwa anak-anak yang masihduduk dibangku SD sering mendapatkan tugas dari guru-guru mereka di sekolah atau di empat les untuk mencari sumbersumber informasi yang berhubungan dengan tugas mereka di internet.

Internet sebagai sumber belajar disatu sisi memberi kemudahan namun disisi lain ada resiko yang perlu diperhatikan. Guru perlu memberikan perhatian terhadap murid-murid karena ada hal-hal yang bisa mempengaruhi murid pada tindakan yang negatif yang bisa mengganggu proses pembelajaran juga merusak kejiwaan siswa karena banyak hal bertentangan dengan moral dan agama. Internet selain memberikan informasi -informasi juga merupakan saran hiburan bagi siswa. Banyak permainan yang bisa membuat mereka terlena melupakan waktu belajar mereka. Menurut Aprilia (2014) internet juga bisa merubah gaya hidup. Gaya hidup yang tidak sesuai dengan pola kehidupan didalam lingkungan yang mereka tempati,dalam hal ini mode pakaian yang kurang sopan sebab memperlihatkan auratnya. Diharapkan guru lebih memberikan perhatian terhadap murid-murid. Hal ini dikarenakan muatan internet masih banyak yang menayangkan berbagai suasana kurang sehat, tidak menunjang terhadap pembentukan kualitas SDM yang diharapkan; bahkan akhir-akhir ini banyak isi internet yang tidak sesuai dengan moral dan ajaran agama. Ini adalah permasalahan sekaligus tantangan berat bagi perkembangan pendidikan. Maunah, (2016) Interaksi yang baik atara siswa dan guru dapat mengurangi resiko pengggunaan internet sebagai sumber belajar siswa.

Internet merupakan salah satu alat pembelajaran, keberhasilan pembelajaran dengan internet sebagai sumber belajar, harus ditunjang oleh adanya interaksi yang maksimal antara siswa dengan guru di sekolah, dan adanya pola pendidikan aktif dalam interaksi tersebut.Dari sisi teknologi informasi, dunia internet memungkinkan perombakan total konsep pendidikan yang selama ini berlaku. Informasi yang diperlukan siwa untuk menunjang pelajaran yang diajarkan disekolah dapat diperoleh dengan mudah dan relatif murah. Internet telah menghilangkan batasan ruang dan waktu yang selama ini membatasi dunia pendidikan. Sebenarnya internet bisa menjadi sumber pembelajaran alternatif yang cukup efektif dan efisien.Selama ini, yang umum dikenal sebagai sumber belajar adalah guru dan buku. Semakin lama sumber belajar tradisional ini 
semakin terbatas, baik jumlah maupun distribusi. Dalam hal ini internet bisa menjadi subtitusi yang sifatnya untuk melengkapi, melainkan bukan untuk menggantikan peran guru secara keseluruhan.

Menurut Kristiyanti (2010) internet bukanlah pengganti sistem pendidikan. Kehadiran internet lebih bersifat suplementer dan pelengkap. Metode konvensional tetap diperlukan, hanya saja dapat dimodifikasi ke bentuk lain. Metoda Talk and Chalk dimodifikasi menjadi online conference. Media internet ini sebenarnya mempunyai fungsi yang hampir sama dengan buku, yakni program yang diputar sesuai dengan kebutuhan dan visualisasi pada buku sangat kurang dan tidak menarik jikadibandingkan visualisasi edia elektronik. Media komputer berbasis internet menjadi sumber belajar acuan yang cukup digemari sekarang ini. Selain berfungsi sebagai sumber informasi melalui situs- situs yang menyediakan beberapa materi, internet adalah media diskusi ilmiah online. Dengan internet, diskusi yang diadakan dapat berlangsung kapan saja dan oleh siapa saja yang tidak berada dalam satu lokasi.

Untuk mencapai tingkat pembelajaran yang efektif, sudah semestinya setiap guru memanfaatkan teknologi dalam strategi pembelajaran dan penggunaan media pembelajaran. Hal ini tentunya diperlukan dukungan dari institusi pendidikan atau sekolah

\section{KESIMPULAN DAN SARAN}

\subsection{KESIMPULAN}

Data penelitian ini menghasilkan kesimpulan :

1. Persepsi teknologi informasi, kemudahan dan resiko mempengaruhi 51,3\% dari keputusan guru Sekolah Menengah Pertama dalam pemanfaatan internet sebagai sumber belajar, sedang 48,7\% lainnya dipengaruhi oleh faktor lainnya

2. Persepsi kemudahan mempunyai pengaruh paling tinggi yaitu sebesar 0.465 , dan persepsi teknilogi informasi mempunyai pengaruh sebesar 0.441 sedang resiko mempunyai pengaruh sebesar (-0.117) terhadap minat guru Sekolah Menengah Pertama dalam pemanfaatan internet sebagai sumber belajar.

3. Berdasarkan uji $\mathrm{F}$, dengan signifikan sebesar 0.000 lebik kecil dari $\alpha$ sehingga model regresi $\mathrm{Y}=4.133+0.441 \mathrm{X}_{1}+0.465 \mathrm{X}_{2}+(-0.117) \mathrm{X}_{3}$ sudah tepat.

4. Variabel persepsi teknoligi informasi dan persepsi kemudahan berpengaruh positif terhadap minat guru SMP memanfaatkan internet sebagai sumber belajar dengan nilai t-hitung 6.621 dan 8.665 secara parsial, sedang persepsi resiko berpengaruh negatif terhadap minat guru SMP memanfaatkan internet sebagai sumber belajar dengan nilai t-hitung -2,429.

\subsection{SARAN}

1. Penelitian ini dapat dikembangkan pada pengaruhnya terhadap hasil belajar belajar siswa terkait dengan persepsi guru terhadap minat menggunakan internet sebagai sumber belajar siswa.

2. Ruang lingkup penelitian ini baru mencakup Surakarta dan sekitarnya dapat iperluas arealnya atau pun pada jenis sekolahnya 


\section{DAFTAR PUSTAKA}

Aprilia, L. (2014). Pengaruh Internet Terhadap Akhlak SiswaKelas XI SMA Negeri 1 Jatisrono. Skripsi. Program Studi Pendidikan Agama Islam Fakultas Agama Islam Universitas Muhammadiyah, Surakarta

Basyaib, F. (2007). Manajemen Resiko. Grasindo, Jakarta

Davis, F.D. 1989.Perceived usefulness, perceived ease of use, and user acceptance of informationtechnology. MS Quarterly (online), Vol. 13 Iss. 3, pg. 318. http://www.cba.hawaii.edu/chismar/ITM704/DavisTAM 1989.pdf, 5 Mei 2016

King, William R. (2006). A meta-analysis of the technology acceptance model. ScienceDirect: Information \& Management. Vol. 43.:740-755

Kristiyanti, M. (2010). Internet Sebagai Media Pembelajaran Yang Efektif. Majalah IlmiahINFORMATIKA. VolI. No 1:8-29

Maunah, B. (2016). Dampak Regulasi Di Bidang TIK Terhadap Perubahan Perilaku Sosial Siswa Di Sekolah Menengah Kejuruan. Cakrawala Pendidikan. Th. XXXV, No. 2:176-186

Mujib, M. (2013). Pengaruh Penggunaan Internet Terhadap Hasil Belajar Siswa Sekolah Menengah Atas. Skripsi.Kependidikan Islam, UIN Sunan Kalijaga, Yogyakarta

Mutaqin,A. Marethi,I. Syamsuri. (2016). Model Blended Learningdi Program Studi Pendidikan Matematika Untirta Cakrawala Pendidikan, Februari 2016, Th. XXXV, No. 134-141

Prasojo, L.D., Riyanto. (2011). Teknologi Informasi Pendidikan. Gava Media, Yogyakarta

Qodrin .N. (2011). Pengaruh Penggunaan Teknologi Informasi Pembelajaran Berbasis Internet Terhadap Minat Belajar PAI Siswa Kelas VIII SMP N 30 Semarang Tahun Pelajaran 2011/2012. Skrips. Fakultas Tarbiyah, IAIN Walisongo, Semarang

Ramansah (2015).Pemanfaatan Internet Sebagai Sumber Belajar Pendidikan Agama Islam Di Sekolah Menengah Pertama Al-Ishlah Kecamatan Lima Puluh Pekanbaru. Skripsi. UIN Sultan Syarif Kasim, Riau, http://repository.uinsuska.ac.id/id/eprint/1732, 3 Maret 2015

Rochmawati,W. (2012). Perilaku Pemanfaatan Internet. Media Libri-Net Volume : 1 - No. 1

Sidiq, Zulkilfi (2015) Persepsi Guru SDLB terhadap Media Pembelajaran Berbasis Teknologi Informasi Dalam Mendukung Pembelajaran Anak Berkebutuhan Khusus Di Kecamatan Majalaya Kabupaten Bandung, Edutech. Vol 1 No 12

Sunyoto, D. (2012) .Analisis Validitas dan Asumsi Klasik. Gava Media, Yogyakarta.

Tomo, S., \& Utami, Y. R. (2016). Pengaruh Pemanfaatan Internet Terhadap Kegiatan Belajar Siswa di Surakarta. Jurnal Ilmiah SINUS, Vol. 14, 21-32.

Wuryandani,W. Fathurrohman, Ambarwati.U. (2016) ImplementasiPendidikan Karakter Kemandirian Di Muhammadiyah Boarding School. CakrawalaPendidikan, Th. XXXV, No. 208-216. 